\title{
Pemberdayaan Kelompok Wanita Mawar Melalui Teknologi Pengolahan Produk Ayam Pedaging
}

\author{
Selvia Nurlaila ${ }^{1)}$, Joko Purdiyanto ${ }^{2)}$, Malikah Umar ${ }^{3)}$, Bambang Kurnadi ${ }^{4}$ \\ Dosen Peternakan Fakultas Pertanian Universitas Madura ${ }^{1,2,3,4}$ \\ selvia@unira.ac.id
}

\begin{abstract}
The implementation of the community service program can provide information, technology and its application with the hope that this program can increase the economic income of the Mawar women group and can compete by producing high selling products and being able to market them. Bukek Village is one of the villages in Tlanakan District, Pamekasan Regency. The majority of the community's occupations are farming and animal husbandry. The average income is obtained through the head of the family, and most housewives do not have a job. The livestock commodities that are kept include cows, goats, sheep, rabbits, native chickens, laying hens, broilers and ducks. In maintenance it is not uncommon for women to take over this work. Broiler production is one of the poultry products in this region. Initially they did not like to consume broiler meat, but as they gained knowledge about the nutrition of broilers, they wanted to know how to process these broiler products so that all products from broilers and their by-products become products that have a high selling value.
\end{abstract}

Keyword: Processing, Broilers, Bonding Products.

Abstrak

Pelaksanaan Program pengabdian kepada masyarakat dapat memberikan informasi, teknologi dan penerapannya dengan harapan adanya program ini dapat meningkatkan pendapatan ekonomi kelompok wanita Mawar serta bisa berkompetisi dengan menghasilkan produk berdaya jual tinggi dan dapat memasarkannya. Desa Bukek merupakan salah satu Desa di Kecamatan Tlanakan Kabupaten Pamekasan. Mayoritas pekerjaan masyarakat adalah bertani dan beternak. Rata-rata pendapatannya diperoleh melalui kepala keluarga, dan kebanyakan ibu rumah tangga tidak memiliki pekerjaan. Komoditas ternak yang dipelihara antara lain sapi, kambing, domba, kelinci, ayam buras, ayam petelur, ayam pedaging dan itik. Dalam pemeliharaan tidak jarang perempuan mengambil alih pekerjaan ini. Produksi ayam pedaging menjadi salah satu produk ternak unggas di wilayah ini. Awalnya mereka kurang menyukai mengkonsumsi daging ayam ras namun seiring pengetahuan yang mereka dapatkan akan gizi ayam pedaging timbul keinginan untuk mengetahui cara pengolahan produk ayam pedaging ini sehingga semua produk dari ayam pedaging dan hasil ikutannya menjadi produk yang mempunyai nilai jual tinggi.

Keyword: Pengolahan, Ayam Pedaging, Hasil Ikutan. 


\section{PENDAHULUAN}

\section{Analisis Situasi}

Masyarakat Desa Bukek Kecamatan Tlanakan sebagian besar mata pencaharian adalah petani dan peternak yang memperoleh pendapatan dari sektor pertanian, diantaranya tanaman pangan (padi, jagung, kacang hijau dan tembakau). Petani yang dimaksud adalah petani pemilik, petani penggarap, dan buruh tani.

Desa Bukek memiliki kelompok masyarakat yang produktif, salah satunya Kelompok Wanita Mawar yang merupakan perkumpulan ibu rumah tangga yang setiap minggunya mengadakan pertemuan rutin dengan kegiatan antara lain mengaji dan mengadakan arisan. Anggota kelompok wanita ini terdiri dari 6 pengurus dan 94 anggota. Mayoritas kegiatan kelompok wanita yakni membantu pekerjaan kepala keluarga antara lain membantu pekerjaan di sawah dan memelihara ternak.

Kegiatan kelompok ini menghasilkan produk yang dapat memberi tambahan penghasilan mereka misalnya memproduksi dan menjual beberapa camilan. Hal ini dikarenakan faktor ekonomi, yaitu tidak tercukupinya kebutuhan rumah tangga mereka. Sebagai ibu rumah tangga, biasanya perempuan yang bertanggung jawab dalam mengatur rumah tangga, baik menyangkut kesehatan gizi keluarga, pendidikan anak dan pengaturan pengeluaran biaya hidup keluarga.

Komoditas ternak yang dipelihara di Desa Bukek antara lain sapi potong, domba, kambing, kelinci, ayam buras, ayam petelur, ayam pedaging dan itik. Produksi ayam pedaging menjadi salah satu produk ternak unggas di wilayah ini. Awalnya mereka kurang menyukai memelihara dan mengkonsumsi ayam pedaging namun seiring pengetahuan yang mereka dapatkan akan gizi ayam pedaging timbul keinginan untuk mengetahui cara pengolahan produk ayam pedaging ini sehingga semua produk dari ayam pedaging dan hasil ikutannya menjadi produk yang mempunyai nilai jual tinggi.

Melalui program pengabdian kepada masyarakat dapat memberikan informasi, teknologi dan penerapannya dengan harapan adanya program ini dapat meningkatkan produktifitasnya kelompok ini dengan menghasilkan produk, memasarkan dan dapat meningkatkan pendapatan.

\section{Permasalahan Mitra dan Solusi yang Ditawarkan} adalah:

Berdasarkan hasil pemaparan di atas, maka permasalahan yang dihadapi mitra Tabel 1. Permasalahan dan Solusi Mitra

\begin{tabular}{|c|c|c|}
\hline No. & Permasalahan Mitra & Solusi yang Ditawarkan \\
\hline 1. & $\begin{array}{lr}\text { Masih rendahnya } \\
\text { pengetahuan } \\
\text { ketrampilan, kesadaran } \\
\text { dalam pengolahan ayam } \\
\text { pedaging } \\
\text { sumber sebagai } \\
\text { ketahanan pangan dan } \\
\text { pendapatan keluarga }\end{array}$ & $\begin{array}{l}\text { Mitra diberikan Materi penyuluhan meliputi keunggulan } \\
\text { produk pangan asal hewan yakni produk utama dan } \\
\text { produk ikutan ayam pedaging yang diupayakan untuk } \\
\text { pemenuhan pangan hewani dan memberikan nilai jual } \\
\text { yang tinggi. }\end{array}$ \\
\hline 2. & $\begin{array}{l}\text { Mitra belum mampu } \\
\text { mengolah bahan utama } \\
\text { dan bahan ikutan } \\
\text { produk ayam pedaging. }\end{array}$ & $\begin{array}{l}\text { Mitra diberikan bimbingan teknis mengenai cara dan } \\
\text { praktek pengolahan produk utama dan produk ikutan } \\
\text { ternak ayam pedaging serta } \\
\text { packging yang baik dan benar sehingga produk yang }\end{array}$ \\
\hline
\end{tabular}




\begin{tabular}{|c|l|l|}
\hline & & $\begin{array}{l}\text { dihasilkan lebih higienis, tahan lama dan membuat } \\
\text { konsumen tertarik. }\end{array}$ \\
\hline 3. & $\begin{array}{l}\text { Mitra belum memiliki } \\
\text { kerjasama dengan pihak } \\
\text { lain sehingga akses } \\
\text { informasi tidak terjalin }\end{array}$ & $\begin{array}{l}\text { Mitra diberikan cara pemasaran produk yang benar } \\
\text { sehingga terdapat penerimaan sebagai sumber tambahan } \\
\text { pendapatan }\end{array}$ \\
\hline
\end{tabular}

\section{METODOLOGI KEGIATAN}

Metodologi dari kegiatan ini adalah metode penyuluhan dan bimbingan teknis penganekaragaman produk utama dan olahan hasil ikutan ayam pedaging. Anggota kelpompok wanita Mawar dan masyarakat sekitar mitra akan diberikan penyuluhan dan bimbingan teknis mengenai produk utama dan olahan hasil ikutan ayam pedaging berupa daging ayam, usus, ceker dan kulit ayam. Pelatihan itu antara lain mengenai pengenalan nilai gizi yang terkandung dalam hasil ikutan ternak unggas dan teknologi pengolahannya. Anggota kelompok dan Masyarakat juga dibimbing dalam pemasarannya.

\section{HASIL DAN PEMBAHASAN}

Tahapan yang dilakukan oleh Tim Pelaksana dalam penerapan teknologi baru ini telah dipertimbangkan langkah-langkah yang akan dilaksanakan baik secara teknis dan nonteknis. Tim Pelaksana menyusun rencana kinerja dibuat suatu rencana kegiatan dan jadual kegiatan sehingga mulai dari perencanaan, pengorganisasian kegiatan, pelaksanaan dan evaluasi kegiatan dapat terlaksana dengan sesuai dengan target dan sasaran yang ingin dicapai.

\section{Survei Lokasi}

Kegiatan survei dilakukan pada tanggal 20 Agustus 2020. Survei ini bertujuan untuk mengidentifikasi kondisi lapangan mitra pengabdian. Kegiatan identifikasi dilakukan dengan mendatangi daerah mitra yang berada di Dusun Utara Desa Bukek Kecamatan Tlanakan Kabupaten Pamekasan. Tim pelaksana pengabdian mendiskusikan mengenai rencana pengabdian yang akan dilakukan dan menyusun agenda kegiatan pengabdian. Berdasarkan hasil diskusi disarankan agar penyuluhan dilakukan pada hari minggu dimana aktivitas perkulihan sedang libur sehingga para dosen dan mahasiswa lebih fokus dalam pelaksanaan pengabdian ini. Pelatihan dilakukan pada tanggal 31 Oktober 2020; 06, 13, 20 November 2020 dan selama masa pengolahan produk utama dan ikutannya dibantu serta dipantau oleh beberapa mahasiswa. Selanjutnya telah disepakati bahwa ketua Kelompok Wanita Tani beserta sekretaris bertanggung jawab mengedarkan undangan. Sehubungan dengan lokasi kegiatan pengabdian maka disepakati akan dilaksanakan di salah satu rumah anggota kelompok.

Kerjasama ini juga akan diperkuat dengan dukungan dari keterlibatan 3 orang mahasiswa dalam pelaksanaan pengabdian masyarakat ini. Mahasiswa melalui penerapan IPTEKS bagi masyarakat ini akan banyak mendapatkan pengalaman dan mengasah kreativitas dan cara berpikir yang inovatif dalam pengembangan ilmu pengetahuan dan teknologinya. Selama kegiatan berlangsung pelaksanaan kegiatan akan dikoordinasikan oleh ketua tim.

\section{Penyuluhan dan Bimbingan Teknis}

Kegiatan penyuluhan dan bimbingan teknis penganekaragaman produk utama dan olahan hasil ikutan ayam pedaging dilaksanakan dengan melibatkan seluruh anggota kelompok serta masyarakat sekitar lokasi kelompok. Menurut Rakhmadi., dkk (2018) kegiatan pengabdian kepada masyarakat melalui metoda penyuluhan mengenai teknologi 
pengolahan hasil ikutan ternak unggas (Kulit, Usus, Ceker) menjadi diversifikasi produk unggas yang berdaya jual tinggi dan mencegah penumpukan limbah.

Antusiasme para peserta sangat besar dalam mengikuti seluruh rangkaian kegiatan yang diselenggarakan. Jumlah peserta yang hadir adalah 35 orang dengan rentan usia berkisar antara 25-50 tahun. Pemberdayaan Anggota Kelompok Wanita Mawar melalui Teknologi Hasil Ternak Ayam Pedaging dan Ikutannya Menjadi Produk Berdaya Jual Tinggi Di Desa Bukek Tlanakan Kabupaten Pamekasan mendapatkan respon yang sangat bagus dari kelompok Tani Mawar tersebut. Hal ini dikarenakan dalam pengolahannya limbah unggas ini tidak memerlukan biaya yang sangat tinggi.

Kelompok ini juga diajarkan sekalian tentang mutu pangan, antara lain cara pembersihan limbah ternak unggas tersebut serta mendapatkan difersifikasi produk unggas. Disamping itu juga dapat meningkatkan taraf hidup masyarakat Desa Bukek Kecamatan Tlanakan, karena produk ini dapat dijual ke berbagai pihak.

Metode yang dilaksanakan pada Ipteks bagi masyarakat ini adalah melalui pemberdayaan masyarakat/pengembangan SDM melalui penyuluhan, pelatihan dan pendampingan. Pendekatan melalui (1) transfer teknologi tepat guna, (2) pengembangan wawasan kewirausahaan, (3) Pengembangan manajemen usaha. Pembinaan dan pembelajaran pada Peserta yakni tentang pengolahan hasil ikutan ternak unggas. Dilakukan juga interaksi melalui tanya jawab terkait hal tersebut kepada peserta pelatihan. Antusias peserta sangat tinggi karena selama ini umumnya peserta pelatihan hanya mendengar dan melihat melalui media elektronik saja, sehingga melalui pelatihan ini mereka dapat secara langsung melihat dan mempraktekkannya pada kegiatan selanjutnya.

Tahapan pelaksanaan kegiatan ini diawali dengan penjajagan dan sosialisasi program Ipteks untuk melakukan pendampingan dan kerjasama dengan petani atau mitra usaha dalam pengembangan Ipteks dan usaha kecil mikro. Selanjutnya membuat kesepakatan dan kerjasama pengembangan usaha pedesaan, merencanakan pengembangan SDM melalui penyuluhan, pelatihan dan pendampingan kepada mitra usaha. Mitra usaha diberikan pelatihan dan demo tentang penanganan dan pengolahan pascapanen, manajemen usaha, dan akses pemasaran usaha. Pelatihan diberikan sampai kelompok usaha memiliki keterampilan dan produk yang siap dipasarkan dan memiliki produk yang berkualitas.

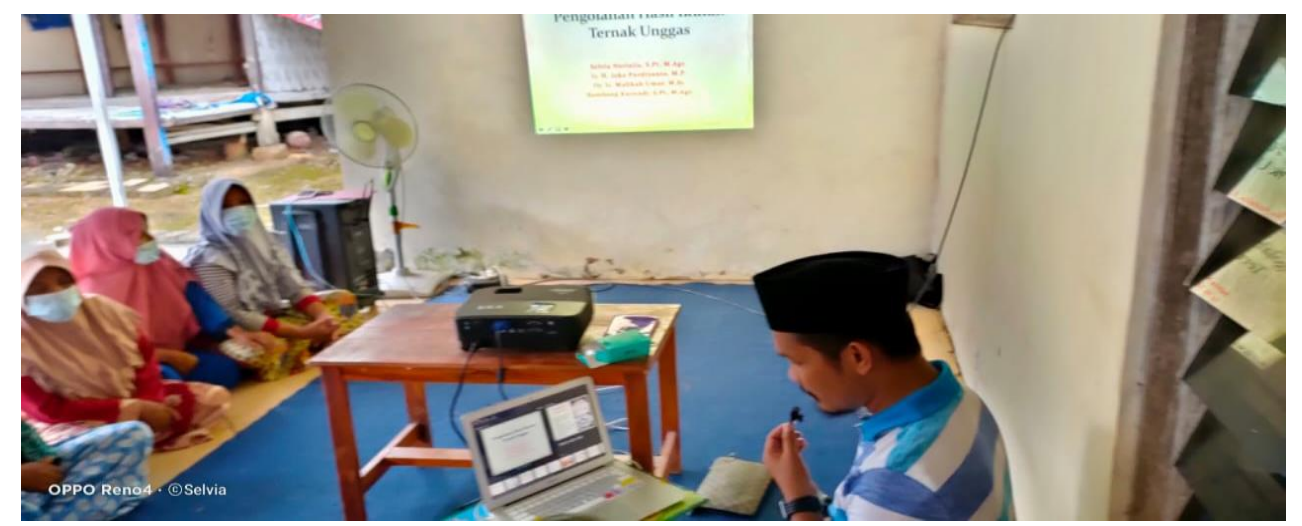

Gambar 1. Penyuluhan dan Bimbingan Teknis pada Anggota Kelompok Wanita Mawar

Kegiatan ini mendapatkan respon positif yang ditandai dengan antusiasme para peserta terutama tahap diskusi dengan pemateri. Kegiatan ini juga berhasil meningkatkan kesadaran peserta tentang pengolahan hasil ikutan ternak unggas khususnya usus menjadi anekaragam produk olahan. Seluruh peserta bersedia mengikuti seluruh rangkaian kegiatan yang akan dilaksanakan oleh tim pelaksana. 


\section{Pembuatan Nugget Ayam}

Nugget ayam merupakan salah satu produk pangan cepat saji yang saat ini dikenal baik oleh masyarakat. Nugget, seperti juga sosis, burger, dan corned, telah menjadi salah satu pilihan masyarakat sebagai produk pangan yang praktis. Nugget terbuat dari daging cincang yang telah dibumbui (Nugraha., dkk, 2019). Bahan baku utama yang digunakan untuk memproduksi chicken nugget adalah daging ayam. Daging yang digunakan sebaiknya daging ayam giling, tujuannya agar mempermudah ketika proses pencampuran atau pemblenderan sehingga nantinya didapatkan adonan chicken nugget yang halus dan rata. Bahan pelengkap chicken nugget adalah air dan es batu, bumbu-bumbu (lada, bawang putih, pala) dan garam (Bintoro, 2008).

Tahapan pertama pembuatan nugget adalah penggilingan dan pencampuran dengan tepung dan bambu. Tujuan penggilingan ini adalah meningkatkan luas permukaan daging untuk membantu ekstraksi protein. Proses penggilingan sebaiknya dilakukan dengan menambahkan es pada saat penggilingan daging. Tahap kedua adalah pengukusan. Tahap ketiga adalah proses batter dan breading. Perekat tepung (batter) merupakan campuran yang terdiri dari air, tepung pati, dan bumbu-bumbu yang digunakan untuk mencelupkan produk sebelum peoses breading. Pelumuran tepung roti (breading) merupakan pelapisan produkproduk makanan dengan menggunakan tepung roti. Tahapan ke empat adalah pre-frying adalah langkah yang terpenting dalam proses batter dan breading.

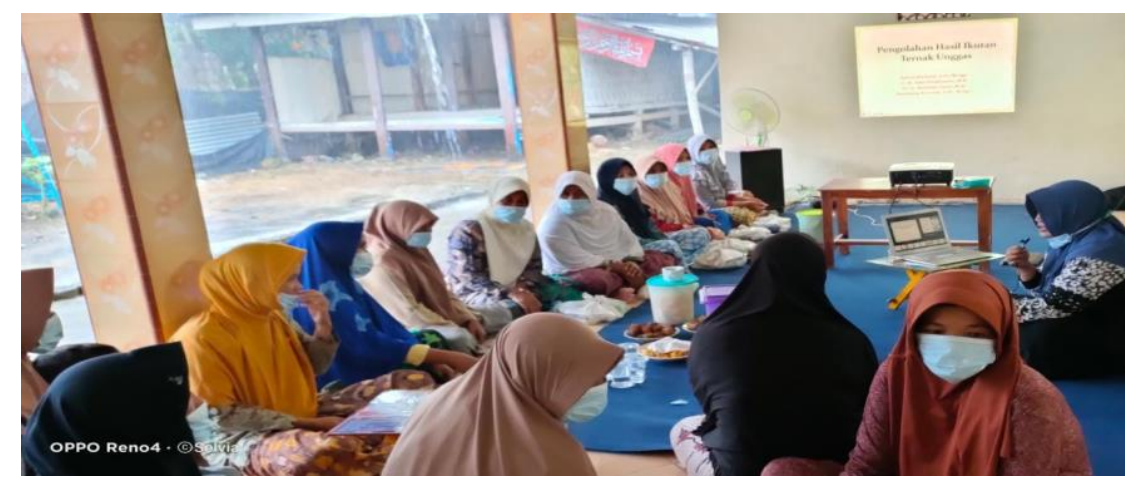

Gambar 2. Pemaparan Pembuatan Nugget Ayam

Penggorengan awal dilakukan dengan menggunakan minyak mendidih sampai setengah matang. Penyimpanan beku ini bertujuan untuk memperpanjang masa simpan produk. Penggorengan awal dilakukan karena pada produk akhir hanya berlangsung sekitar empat menit, atau tergantung pada ketebalan dan ukuran produk

\section{Pembuatan Keripik Usus Ayam}

Keripik merupakan makanan ringan atau camilan bercita rasa renyah dan gurih. Pada umumnya, keripik dibuat dengan bahan berupa umbi-umbian, sayuran, maupun buah-buahan yang diiris tipis dan kemudian digoreng. Namun ada lagi salah satu jenis keripik yang sudah cukup populer dan disukai hampir semua orang yaitu keripik usus. Sesuai namanya, keripik usus berbahan utama dari 'jeroan' yakni usus ayam.

Memang sedikit sulit untuk mendapatkan bahan utama dari pembuatan kripik ini, yaitu usus mentah. KWT Desa Bukek mendapatkan usus mentah dari pedagang ayam dengan memesannya terlebih dahulu. Tahap pertama dalam pembuatan kripik usus adalah membersihkan usus hingga benar-benar bersih, direndam dengan kapur sirih kemudian tiriskan. Selanjutnya usus dipotong kira-kira sepanjang 2 sampai $4 \mathrm{~cm}$. Setelah dipotong lalu didihkan dengan mencampurkan usus dengan bumbu yang sudah dihaluskan. Bumbu yang digunakan terdiri dari bawang putih, ketumbar, garam, jahe, kunyit, kemiri. 

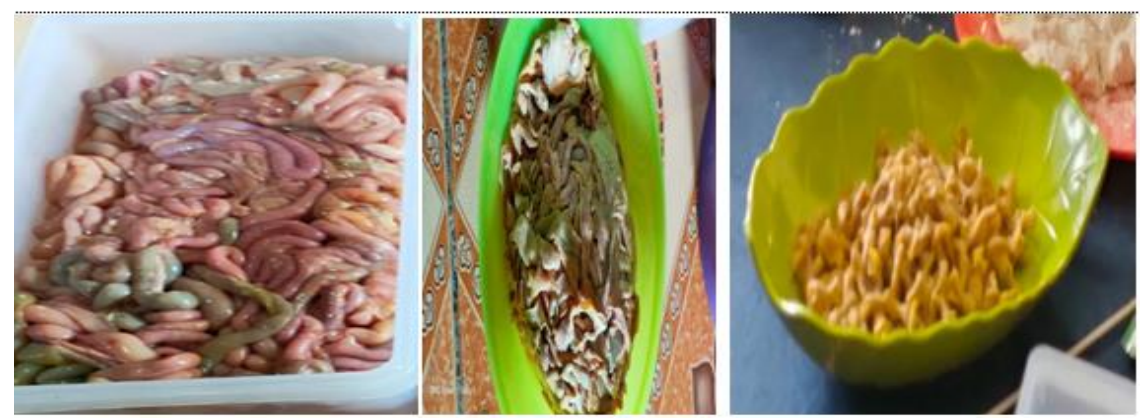

Gambar 3. Usus Ayam Mentah; Usus Ayam Setengah Matang; Kripik Usus Ayam

Untuk pelapisnya menggunakan campuran dari tepung terigu, tepung sagu, garam, kunyit bubuk, penyedap dan lada. Aduk usus dan semua campuran bumbu hingga merata. Proses selanjutnya adalah penggorengan, usus digoreng dengan api sedang hingga warnya berubah menjadi kekuningan. Setelah matang, angkat dan tiriskan kripik usus. Agar kripik bisa lebih awet lagi, kripik dimasukkan ke dalam plastik klip yang bisa ditutup kembali.

Produk olahan usus yang ditransfer pada peserta adalah keripik usus. Awalnya terdapat keraguan para peserta dalam mengolah usus ayam menjadi produk pangan, karena selama ini usus ayam sangat jarang dikonsumsi oleh manusia. Berbekal pedoman dan pengalaman dari tim pelaksana dalam mengolah usus ayam para peserta berhasil memproduksi aneka olahan keripik usus yang bercita rasa lezat. Setelah praktek selesai, dilakukan pengemasan produk dengan pengemas sederhana. Keripik usus dimasukkan ke plastik dengan beberapa ukuran. Dengan harga ecer di pedagang Rp 5.000,00 dan Rp. 10.000,00. Penyajiannya juga dilengkapi dengan saos sambal. Keripik usus ini dipasarkan ke toko camilan, Intansi Pemerintahan, sekolah dan kampus.

\section{Pembuatan Keripik Ceker Ayam}

Ceker ayam yang merupakan hasil samping dari rumah potong ayam atau pengusaha ayam potong yang dijual dalam bentuk sudah disembelih dan dibersihkan bulunya selama ini praktis hanya digunakan untuk masak sup atau direbus untuk diambil kuahnya atau kaldunya saja. Cakar ayam dapat dimanfaatkan untuk mendapatkan nilai ekonomis yang lebih tinggi. Jenis makanan yang berasal dari hasil samping budi daya ayam termasuk kripik ayam ini mulai banyak diproduksi di daerah-daerah yang banyak menghasilkan ayam broiler misalnya di Kabupaten Sidoarjo, Jombang, Mojokerto Jawa Timur (Hisyam, 2013).

Cakar ayam masih dianggap sebagai limbah pemotongan yang memiliki nilai ekonomis rendah, namun jika kita pandai dan kreatif, maka cakar ayam dapat diolah dan dimanfaatkan menjadi barang-barang kerajinan kulit yang mempunyai nilai ekonomis tinggi. Salah satu pemanfaatannya adalah sebagai bahan baku penyamakan kulit, karena tersedia cukup dan pengadaannya terus menerus dapat disediakan, mudah didapat, harga relatif murah, dan memiliki rajah yang bagus. Kulit cakar ayam samak dapat digunakan untuk membuat barang-barang kulit seperti tas, dompet, tali jam tangan, dan lain-lain (Mustakim, 2009).

Prosedur pertama yang dilakukan dalam pembuatan kerupuk kulit ceker ayam adalah pembersihan ceker ayam, pencucian ceker ayam dan mendidihkan ceker ayam selama 15 menit lalu tiriska. Setelah dingin dilakukan pemisahan antara kulit dan tulang ceker ayam . Pemisahan antara kulit dan tulang dilakukan hingga kulit dapat terlepas dengan utuh agar didapatkan gelatin yang bagus. Setelah dipisahkan, kulit ceker dicuci dan ditimbang bobotnya, lalu ditambahkan tepung terigu, tepung sagu, garam, bawang putih, merica, dan ketumbar. Bumbu ditambahkan ke dalam kulit ceker ayam dan diaduk hingga bumbu tercampur sempurna lalu didiamkan selama kurang lebih 10 menit dengan tujuan agar bumbu meresap. Bumbu ditambahkan sesuai dengan persenan yang telah ditentukan sesuai bobot kulit setelah dipisahkan dari tulang. Setelah bumbu meresap lalu kulit ceker digoreng sampai 
menguning. Hasil keripik ceker ayam digoreng untuk dijadikan makanan cemilan dan dikemas.

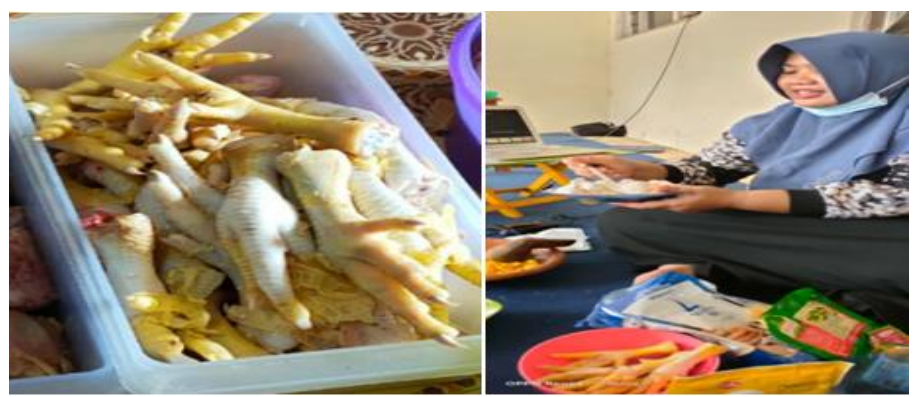

Gambar 4. Proses Pembuatan Keripik Ceker Ayam

\section{Pembuatan Keripik Kulit Ayam}

Ayam menjadi hewan unggas yang semua bagian tubuhnya bisa dimanfaatkan sebagai bahan baku makanan atau kerajinan. Hal ini membuat kebutuhan akan ayam semakin meningkat dalam setiap waktu. Selain dagingnya yang enak dimakan bagian lainnya juga bisa dimanfaatkan hal inilah yang membuat ayam selalu dibutuhkan. Olahan dari bahan ayam semakin banyak setiap waktunya dan semakin beragam pula inovasinya. Salah satunya camilan dari bahan ayam yaitu keripik kulit ayam. Kulit ayam jika digoreng dengan tepung maka akan menghasilkan rasa istimewa. Membuat keripik kulit ayam banyak diburu oleh masyarakat. Camilan dari bahan kulit ayam ini bisa dijadikan usaha dengan prospek keuntungan fantastis. Target pasar pada camilan kulit ayam cukup tinggi, hampir semua kalangan masyarakat menyukai kelezatan dari keripik kulit ayam. Proses mengolah keripik kulit ayam ini pun sangat mudah dan praktis. Usaha keripik kulit ayam bermodal kecil hal ini karena bahan kulit ayam yang terjangkau.

Bahan baku kulit ayam dapat dibeli dengan mudah dipasar atau para pengusaha pemotongan ayam. Harga bahan baku kulit ayam terjangkau dan mudah ditemukan. Selain membutuhkan bahan baku kulit ayam, bawang putih, tepung terigu, tepung sagu, penyedap rasa, kunyit, ketumbar, merica, minyak goreng. Peralatan yang dibutuhkan untuk memproduksi keripik kulit ayam ini misalnya pisau, baskom, wajan, kompor dan gas, peniris minyak, penghalus bumbu, pengemas dan sebagainya.

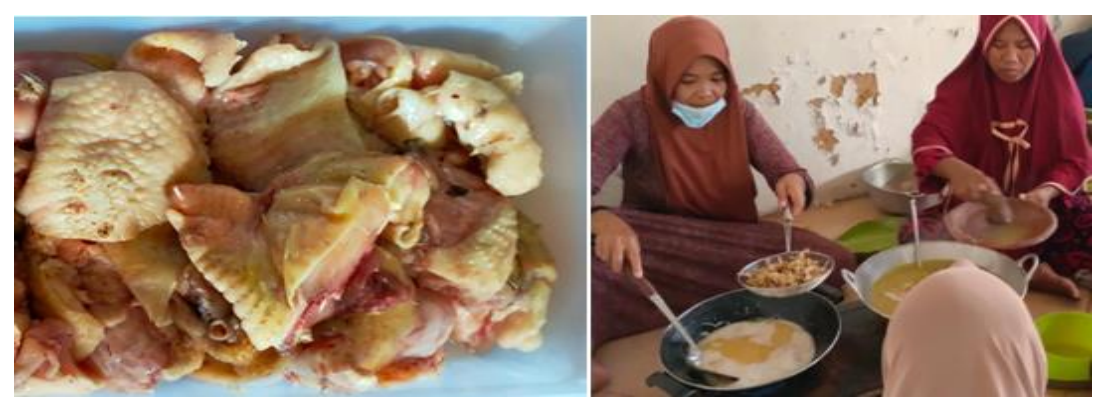

Gambar 5. Kulit Ayam Mentah dan Penggorengan

Cara Membuat Keripik Kulit Ayam (Atom, 2012): Campur semua bahan tepung hingga rata, sisihkan; Lumuri kulit ayam dengan garam, jahe dan jeruk nipis. Diamkan selama 30 menit; Masukkan kulit ayam dalam kocokan telur, gulingkan pada adonan tepung hingga rata di semua bagian; Jika ingin hasil tepung yang lebih tebal, ulangi memasukkan kulit ayam ke dalam telur, lalu gulingkan lagi pada tepung; Goreng kulit ayam dalam minyak panas menggunakan api sedang hingga kuning keemasan kemudian angkat dan tiriskan. 


\section{KESIMPULAN DAN SARAN \\ Kesimpulan}

Kegiatan pemberdayaan kelompok wanita mawar meliputi kegiatan penyuluhan dan bimbingan teknis penganekaragaman produk olahan hasil ikutan ternak unggas dilaksanakan dengan melibatkan seluruh anggota kelompok serta masyarakat sekitar lokasi kelompok. Adapun teknologi pengolahan yang telah dilaksanakan antara lain pembuatan nugget ayam, keripik usus ayam, keripik ceker ayam dan keripik kulit ayam telah dilaksanakan dengan baik. Peserta pengabdian telah mampu mengolah produk utama olahan ayam dan hasil ikutannya sehingga bernilai jual tinggi serta memasarkan hasil poduk ini untuk meningkatkan pendapatan kelompok.

\section{Saran}

Kegiatan Program Kreativitas Masyarakat yang dilakukan oleh Universitas Madura, sangat menunjang kelompok wanita tani Desa Bukek, Kecamatan Tlanakan Kabupaten Pamekasan, sehingga diharapkan kegiatan ini dapat berjalan terus, dan dapat ditingkatkan pada jenis ternak dan produk lainnya.

\section{Ucapan Terima Kasih}

Terimakasih kepada Rektor Universitas Madura Pamekasan, yang telah memberikan kesempatan untuk pengabdian di wilayah mitra Kelompok Wanita Mawar Desa Bukek Kecamatan Tlanakan Pamekasan

\section{DAFTAR PUSTAKA}

Atom. 2012. Cara Membuat Keripik Usus. http://cara-tips-membuat.blogspot. com/2012/10/cara-membuat-keripik-usus.html\#. Diakses 23 November 2021. Pukul 10.00 WIB.

Bintoro, V. P. 2008. Teknologi Pengolahan Daging dan Analisis Produk. Universitas Diponegoro, Semarang.

Hisyam, 2013. Kripik Ceker Ayam, Alternatif Usaha yang Menjanjikan. http://ekonomi.kompasiana.com/wirausaha/2013/11/28/kripik-cekerayam-alternatif-usaha-yang-menjanjikan. Diakses pada tanggal 28 November 2021 pukul 16.00 WIB.

Mustakim. 2009. Pengaruh Penggunaan Kuning Telur Ayam Ras dalam Proses Peminyakan terhadap Kekuatan Tarik, Kemuluran, Penyerapan Air dan Kekuatan Jahit Kulit Cakar Ayam Pedaging Samak Kombinasi (Krom-Nabati). [Jurnal Ilmu dan Teknologi Hasil Ternak], 4(2):18-26.

Nugraha, BD. Iswoyo, Sampurn, Adi . 2019. Sifat Fisiokimia dan Oganoleptik Nugget Ayam dengan Penambahan Jenis Tepung yang Berbeda. Fakultas Teknologi Pertanian Universitas Semarang bagasdwinugaraha@gmail.com

Rakhmadi, Ade. Allismawita. Berliana, Elisa. 2018. Penyuluhan Teknologi Pengolahan Hasil Ikutan Ternak Unggas (Usus,Ceker dan Kulit) Ayam Broiler Menjadi Produk Berdaya Jual Tinggi Di-Kanagarian Koto Baru. Kecamatan Sungai Tarab Kabupaten Tanah Datar. http://repo.unand.ac.id/17424/1/Laporan\%20Akhir\%20PENGABDIAN.pdf. Diakses Tanggal 25 November 2020. Pukul 12.00 WIB. 